\title{
Steroidogenic and morphological characteristics of granulosa and thecal compartments of the differentiating rabbit corpus luteum in culture
}

\author{
K.-C. M. Yuh, R. M. Possley, R. K. Brabec and P. L. Keyes \\ Department of Physiology and Reproductive Endocrinology Program, 7793 Medical Science II, \\ The University of Michigan, Ann Arbor, Michigan 48109, U.S.A.
}

\begin{abstract}
Summary. On the day after ovulation, the thecal tissue and associated mural granulosa lutein cells of the rabbit corpus luteum were separated from the granulosa lutein 'core' by dissection and these tissues were cultured separately or together (whole corpus luteum) in defined medium for 10 days on stainless-steel grids. The medium was changed completely every $24 \mathrm{~h}$. Replicate tissues were cultured with testosterone $(10 \mathrm{ng} / \mathrm{ml})$, but no other hormones were added to the medium. Progesterone production increased during the first 2 days of culture for whole corpus luteum, granulosa lutein cells and the thecal compartment which also included granulosa lutein cells. After 3 days, the production of progesterone declined gradually, but was still detectable on Day 10. The production of the metabolite, 20 $\alpha$-dihydroprogesterone, by whole corpus luteum was equal to or greater than that of progesterone. Without the addition of testosterone, the granulosa lutein cells produced little ( $10 \mathrm{pg} /$ culture) oestradiol during 1 day of culture, but the thecal compartment and whole corpus luteum each produced about $100 \mathrm{pg} /$ culture on Day 1 and declining quantities over the next 2 days. In the presence of testosterone added to the medium, the formation of oestradiol was greatly increased for all tissues for 5-6 days of culture, after which time oestradiol was no longer detectable with or without testosterone in medium. Transmission electron microscopy of cells after 10-12 days of culture revealed fine structure that is characteristic of luteal cells, including abundant smooth endoplasmic reticulum, lipid droplets, and junctions between the luteal cells. The corpus luteum in culture resembles the corpus luteum in situ in that steroidogenesis and differentiation can proceed for a period after ovulation without extrinsic hormonal stimulation.
\end{abstract}

\section{Introduction}

After ovulation, the corpus luteum in a number of species has an intrinsic capacity for further development and for the secretion of progesterone in the absence of the pituitary (Deanesly, Fee $\&$ Parkes, 1930; Vande Wiele et al., 1970; Rothchild, 1981). This apparent autonomy may be short-lived, as in the rabbit, in which the corpus luteum persists for only about 4-5 days when the animals are hypophysectomized within a few hours after ovulation (Smith \& White, 1931) or the day after ovulation (Keyes, Yuh, Bill \& Gadsby, 1984; Yuh, Bill \& Keyes, 1984). To investigate the nature of this autonomy of the young corpus luteum, we have placed the corpus luteum and its constituent compartments in culture and determined their steroidogenic characteristics under defined conditions.

\section{Materials and Methods}

Animals and treatments. Sexually mature Dutch rabbits were housed in a temperature-controlled room $\left(18-20^{\circ} \mathrm{C}\right)$ with $12 \mathrm{~h}$ light daily and with a daily ration of rabbit chow. Ovulation was induced 
by mating the rabbits with a vasectomized male; for cultured cells obtained for electron microscopy, rabbits were induced to ovulate with $10 \mu \mathrm{g}$ GnRH (Parke Davis, Ann Arbor, MI), i.m. GnRH was used to ensure ovulation in a number of rabbits on the same day. On Day 1 of pseudopregnancy (19-25 h after mating), animals were anaesthetized with $12 \mathrm{mg}$ xylazine $/ \mathrm{kg}$, i.m. (Cuttler Labs. Inc., Shawnee, Kansas), followed $10 \mathrm{~min}$ later by $60 \mathrm{mg}$ ketamine hydrochloride $/ \mathrm{kg}$, i.m. (Bristol Labs, Syracuse, New York) and the corpora lutea were removed.

Culture of luteal tissues. To determine the steroidogenic capacity of granulosa lutein cells, the inner granulosa lutein 'core' was removed from Day 1 corpora lutea by dissection. The inner granulosa lutein 'core' separates from mural granulosa lutein cells but the thecal compartment always included some attached granulosa lutein cells. Each culture dish contained the thecal comparrtment, or granulosa lutein cell 'core', or the two combined from a single corpus luteum. Whole corpus luteum refers to the thecal compartment and granulosa lutein tissues separated but cultured together in the same dish or the corpus luteum without separation of the two compartments. Replicate cultures were run for each animal and a mean value for steroid in medium determined; this value was considered a single observation $(n=1)$. The tissues were cultured on stainless-steel grids in $2 \mathrm{ml}$ Dulbecco's Modified Eagle Medium (with L-glutamine, $4500 \mathrm{mg}$ D-glucose/litre and $\left(\mathrm{NaHCO}_{3}\right)$ and Ham's F-12 Nutrient Mixture, 1:1 (Gibco, Grand Island, New York), $10 \mathrm{~mm}$-Hepes, 100 i.u. penicillin $/ \mathrm{ml}, 100 \mu \mathrm{g}$ streptomycin $/ \mathrm{ml}$, in the presence or absence of $10 \mathrm{ng}$ testosterone $/ \mathrm{ml}$. This concentration of testosterone is far in excess of the oestradiol formed, and is assumed to be a saturating substrate concentration. Two experiments were performed to determine the effect of serum $(20 \%)$ on progesterone production. Tissues were cultured in $95 \%$ air, $5 \% \mathrm{CO}_{2}$, and with high humidity at $37^{\circ} \mathrm{C}$. The medium was changed completely every $24 \mathrm{~h}$ and frozen for subsequent determination of steroids.

Corpora lutea were also obtained from three Day-4 pseudopregnant rabbits. Each corpus luteum was sliced in half and the halves of two corpora lutea from each rabbit were cultured together for $9 \mathrm{~h}$ under conditions described above. Replicate luteal tissues were cultured in the presence of testosterone $(10 \mathrm{ng} / \mathrm{ml})$. The medium was changed completely every $3 \mathrm{~h}$ in this particular experiment.

Radioimmunoassays. Progesterone and its metabolite, 20 $\alpha$-dihydroprogesterone, in medium were measured directly without extraction as described previously (Yuh \& Keyes, 1981) by the procedures of Niswender (1973) and Bender, Miller, Possley \& Keyes (1978). The $50 \%$ binding points for progesterone and $20 \alpha$-dihydroprogesterone assays were $165 \mathrm{pg}$ and $300 \mathrm{pg}$, respectively; the activity of medium alone (blank) was negligible $(<10 \mathrm{pg} / \mathrm{ml})$. Oestradiol $-17 \beta$ in medium was also measured directly by a modified procedure of England, Niswender \& Midgley (1974), since measurements of oestradiol with or without extraction, and with or without extraction and chromatography were not different. The $50 \%$ binding point was $5.5 \mathrm{pg}$; the activity of medium alone (blank) ranged from 1 to $4 \mathrm{pg} / \mathrm{ml}$ and was subtracted. Tissue contents of progesterone and oestradiol-17 $\beta$ were measured after extraction with benzene, and chromatography on Sephadex LH-20; for cultures with serum, progesterone was measured after extraction with petroleum ether.

Protein and DNA determination. Corpora lutea before culture and at the end of 10-day cultures were homogenized in $6 \%$ trichloracetic acid or medium for protein (Lowry, Rosebrough, Farr \& Randall, 1951) and DNA (Burton, 1956) determinations, respectively. Protein standard (bovine serum albumin) and DNA standard (calf thymus DNA) were treated in the same way as samples.

Histology. Luteal tissue was fixed in Bouin's solution, embedded, sectioned at $4 \mu \mathrm{m}$ and stained with haematoxylin and eosin for light microscopy. For electron microscopy, cultures were fixed at room temperature in $2 \%$ formaldehyde- $3 \%$ glutaraldehyde in $0.1 \mathrm{M}$-cacodylate buffer, $\mathrm{pH} 7 \cdot 4$, for $0.5 \mathrm{~h}$, then at $4^{\circ} \mathrm{C}$ for $1.5 \mathrm{~h}$. Samples were then washed in the same buffer containing $5 \%$ sucrose before post-fixation in $2 \%$ buffered $\mathrm{OsO}_{4}$ for $2 \mathrm{~h}$ in the dark. After a brief wash in buffer, samples were dehydrated in graded ethanols and flat embedded in Epon-Araldite resin. Thin sections were 
stained in 3\% uranyl acetate-50\% ethanol and lead citrate (Reynolds, 1963) before viewing in a Philips 201 electron microscope.

\section{Results}

\section{Granulosa and thecal lutein tissues before and after culture}

With the exception of red blood cells, granulosa lutein cells removed the day after ovulation (Day 1) appear very homogeneous and do not appear to be contaminated with other cells (Fig. 1). However, the freshly-isolated thecal or capsular portion of the Day 1 corpus luteum always had a band of granulosa cells attached (Fig. 2). Figure 3 shows the appearance of granulosa lutein cells after 10 days in culture, and Fig. 4 shows the appearance of a whole corpus luteum after 12 days in culture. In Figs 3 and 4, the cells appear luteinized. Examination of the 10-day cultures in the electron microscope (Fig. 5) revealed an abundance of smooth endoplasmic reticulum (SER), in typical tubular form, which was the predominant organelle in the cultured cells. The SER filled most of the cytoplasm and upon close examination the tubules appeared to be arranged in small bundles of parallel tubules. The nuclei were usually located eccentrically in the cells, had one or two nucleoli and exhibited little heterochromatin. In addition to SER, the cytoplasm contained Golgi, mitochondria, lipid droplets, and free polysomes. The Golgi complex was well developed in most cells and usually exhibited stacks with 4-6 cisternae. Mitochondrial cristae were primarily tubular, but tended to be lamellar in some cells. Most mitochondria were round or ovoid, but in some areas of the culture the cells contained mitochondria that appeared more oblong, and with a denser
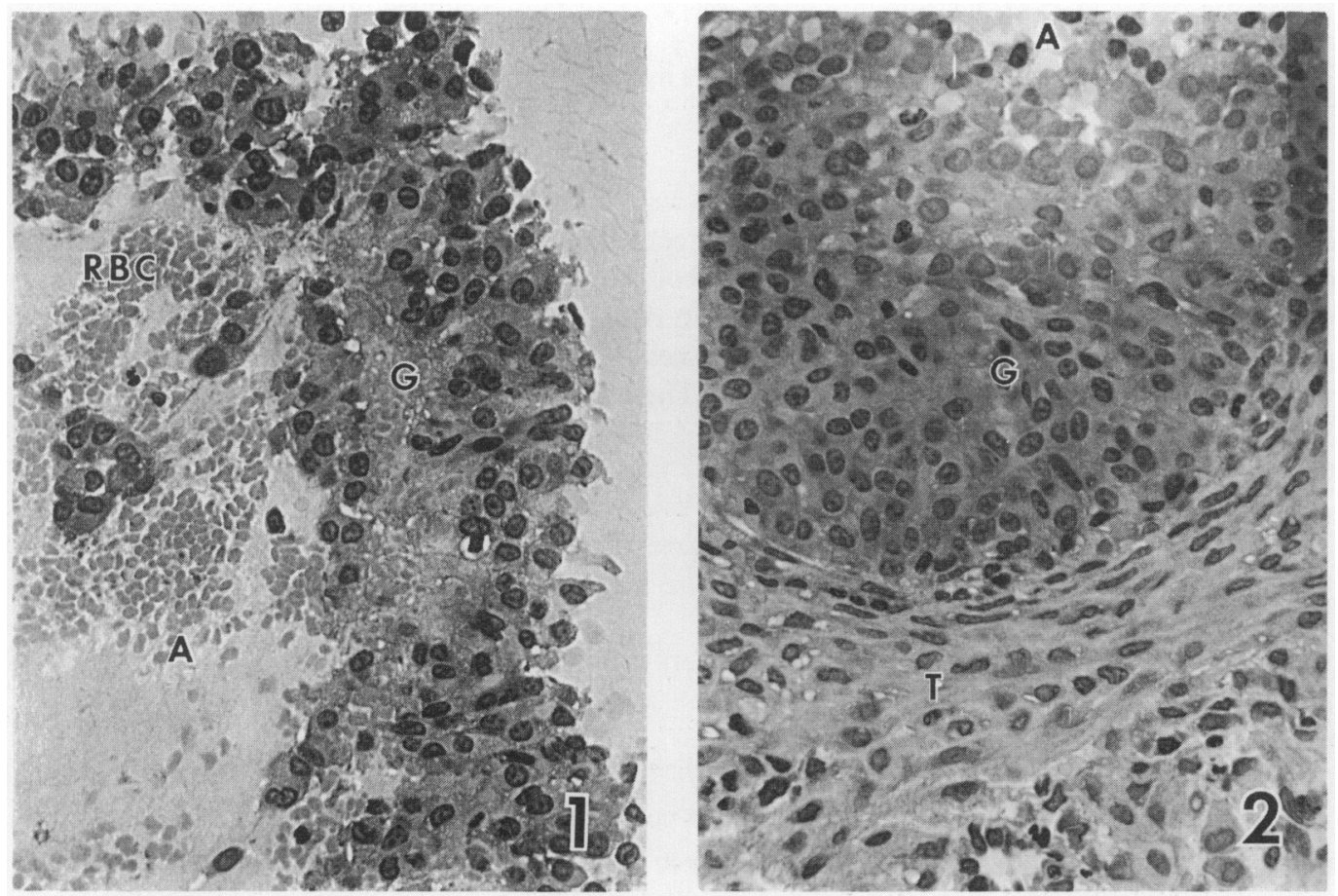

Figs 1 and 2. Freshly isolated granulosa (Fig. 1) and thecal (Fig. 2) lutein tissues from a Day 1 corpus luteum. Note the presence of granulosa lutein cells in Fig. 2. A = antrum; $\mathrm{G}=$ granulosa lutein cells; $\mathrm{T}=$ thecal tissue, $\mathrm{RBC}=$ red blood cells. $\times 300$. 

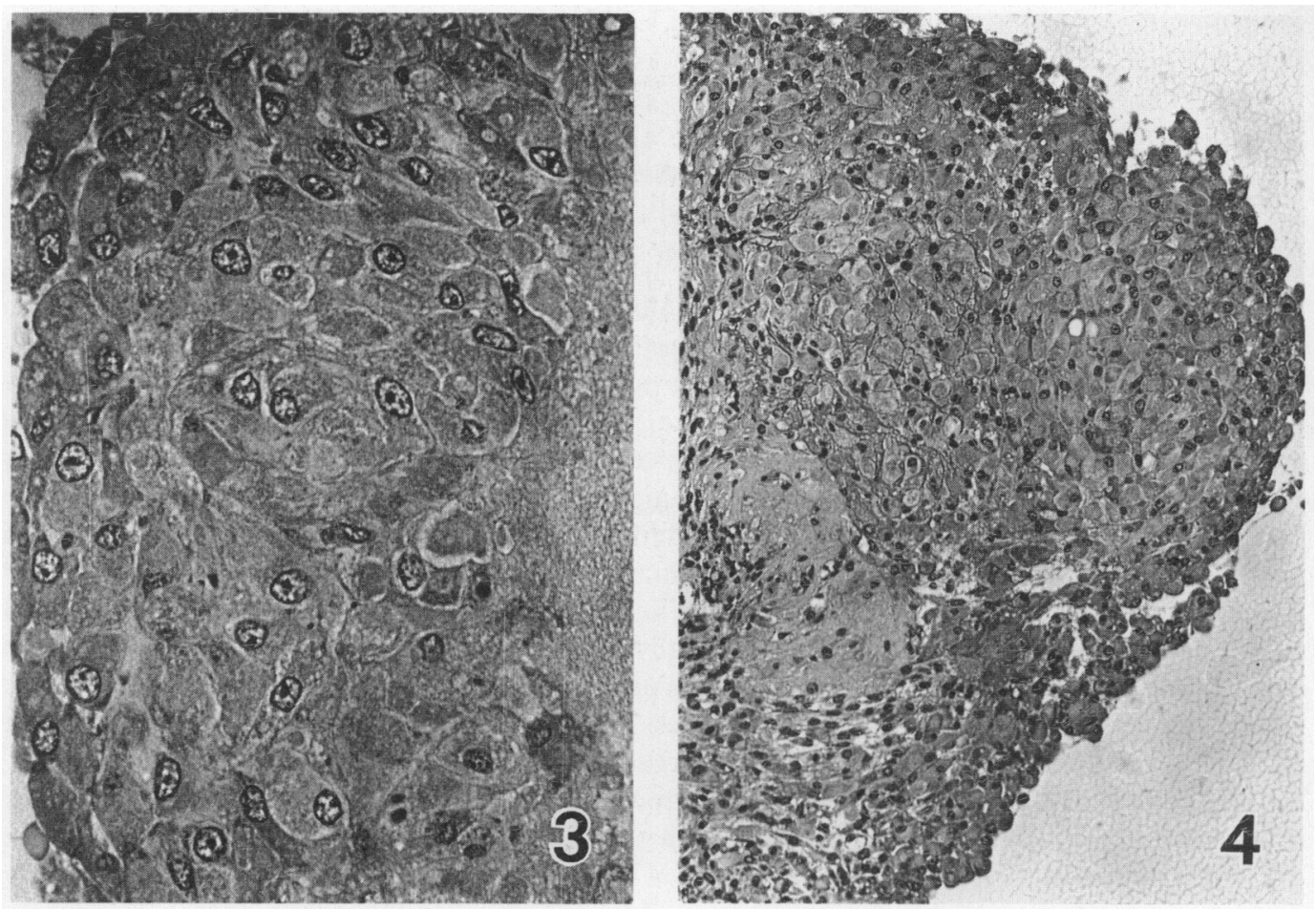

Fig. 3. Granulosa lutein cells after 10 days in culture. $\times 380$.

Fig. 4. Whole corpus luteum after 12 days in culture. $\times 100$. (From Keyes et al., 1984.)

mitochondrial matrix. Lipid droplets generally were found closely associated with mitochondria. Many cells contained areas of filaments, in patches up to $5 \mu \mathrm{m}$ in diameter, which also included occasional profiles of SER and of polysomes. Rough endoplasmic reticulum was not conspicuous in the luteal cells, although it was prominent in occasional fibroblasts seen in the cultures. Free polysomes were abundant in some parts of the cells and the ribosomes making up the polysomes were generally arranged in a helical array. The cell surface displayed occasional microvilli. Junctions, suspected to be gap junctions (Fig. 5 inset), were evident and occasionally numerous between cells.

\section{Luteal tissue content of steroids}

Tissue contents (mean \pm s.e.m.) of progesterone and oestradiol-17 $\beta$ on Day 1 before culture were $9.7 \pm 1.0 \mathrm{ng} /$ corpus luteum (4 animals) and $9.1 \pm 4.0 \mathrm{pg} /$ corpus luteum (5 animals), respectively.

\section{Daily production of progesterone by luteal tissues in culture}

All tissues produced progesterone for at least 10 days, although in declining amounts after Day 3 (Fig. 6). Progesterone produced by the whole corpus luteum was about the same as for the granulosa and thecal compartments combined. 


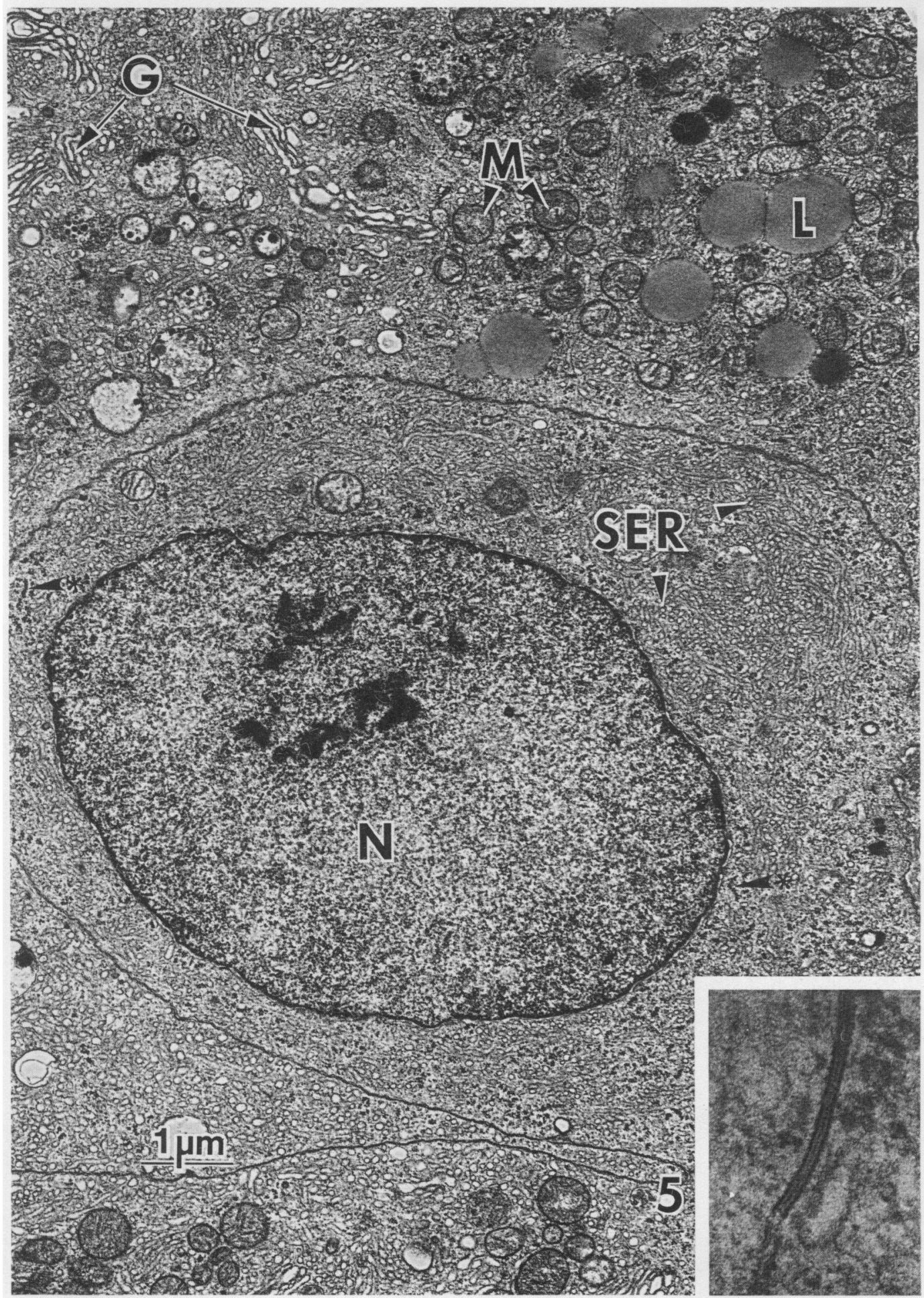

Fig. 5. Luteal cells from a 10-day culture similar to that shown in Fig. 4. Abundant profiles of smooth endoplasmic reticulum (SER) fill most of the cytoplasm. Numerous Golgi complexes $(\mathrm{G})$, mitochondria (M), lipid droplets (L), and a prominent eccentric nucleus (N) were apparent in most cells. Also noted were helical configurations of ribosomes $\left(^{*}\right)$ in polysomes and the absence of rough endoplasmic reticulum. Junctions were common between cells (inset). $\times 14000$; inset, $\times 120000$. 


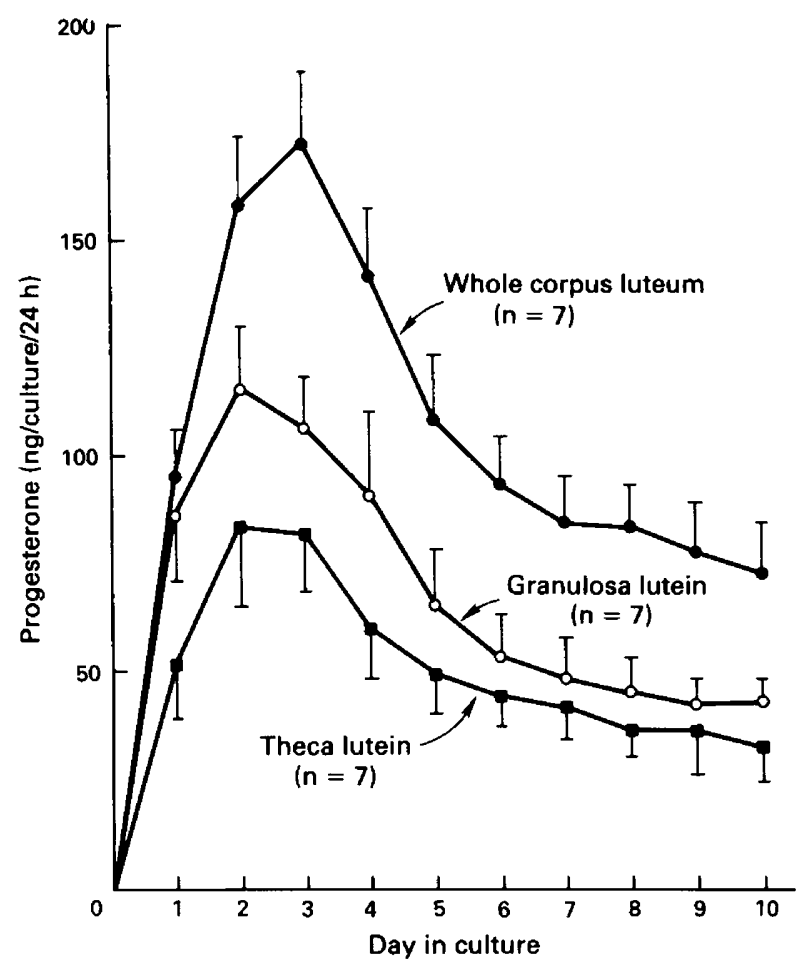

Fig. 6. Daily production of progesterone by cultured rabbit luteal tissues. The data obtained in the absence or presence of testosterone $(10 \mathrm{ng} / \mathrm{ml})$ were combined. The thecal compartment includes attached granulosa lutein cells. Values are mean \pm s.e.m., for. 7 rabbits.

Culture of whole corpus luteum with serum (20\%) from hypophysectomized or nonhypophysectomized rabbits increased the daily production of progesterone 4- to 5-fold, but did not change the overall profile; i.e. an initial rise, followed by a gradual decline through 10 days of culture (data not shown).

\section{Daily production of 20a-dihydroprogesterone by whole corpus luteum in culture}

The production of the metabolite $20 \alpha$-dihydroprogesterone by whole corpus luteum was equal to or greater than the production of progesterone (Fig. 7).

\section{Daily production of oestradiol-17 $\beta$ by luteal tissues in culture}

To assess aromatizing capacity, replicate cultures were conducted in the presence of testosterone $(10 \mathrm{ng} / \mathrm{ml})$. In the absence of exogenous testosterone, granulosa lutein cells produced little $(10 \mathrm{pg}$ ) oestradiol-17 $\beta$ for 1 day (Fig. 8a), whereas the thecal lutein compartment produced oestradiol for 2-3 days (Fig. 8b). In the presence of testosterone added to the medium, the formation of oestradiol by granulosa lutein cells and by the thecal compartment was considerably enhanced but by Day 6 was no longer detectable. Whole corpus luteum explants produced oestradiol for 3-4 days of culture and for 5-6 days in the presence of testosterone (Fig. 8c).

Corpora lutea obtained from three Day-4 pseudopregnant rabbits produced very little oestradiol, if any, a mean of $0.26 \pm 0.04 \mathrm{pg} / \mathrm{mg}$ luteal tissue $/ 9 \mathrm{~h}$, in the presence of testosterone. The progesterone production in these tissues was $33.7 \pm 3.2 \mathrm{ng} / \mathrm{mg}$ tissue $/ 9 \mathrm{~h}$. 


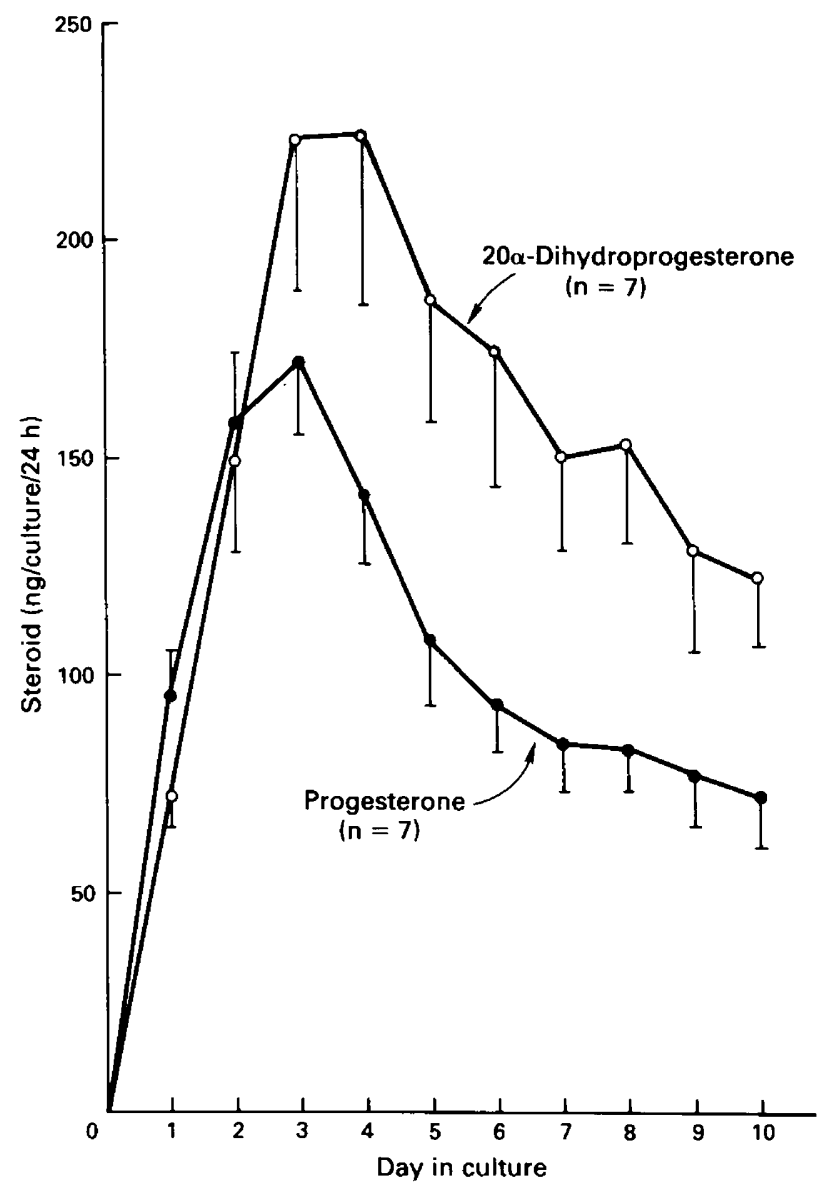

Fig. 7. Daily production of $20 \alpha$-dihydroprogesterone by whole rabbit corpus luteum. The concentrations of $20 \alpha$-dihydroprogesterone and progesterone were measured in the same samples of medium. The progesterone data are from Fig. 6 and are shown for comparison only. Values are mean \pm s.e.m. for 7 rabbits. (From Keyes et al., 1984.)

\section{Effect of testosterone on progesterone and 20a-dihydroprogesterone concentrations}

The addition of testosterone and the elevated amount of oestradiol (see Fig. 8) had no effect on overall accumulation of progesterone in granulosa lutein, thecal lutein, and whole corpus luteum cultures (Fig. 9). The production of the metabolite 20a-dihydroprogesterone into incubation medium of whole corpus luteum without and with testosterone was not different (1466 \pm 267 and $1468 \pm 185 / \mathrm{ng} /$ culture/10 days, respectively).

\section{Luteal tissue content of protein and DNA}

Protein and DNA concentrations were determined in freshly isolated Day 1 tissues and in tissues that had been in culture for 10 days. Table 1 indicates that protein content in the whole corpus luteum was about the same as for the granulosa and thecal lutein tissues combined. About $50 \%$ of protein was lost from the granulosa lutein compartment, the thecal lutein compartment and whole corpus luteum during the 10 days of culture. The DNA contents on Day 1 before culture and at the end of 10-day cultures were (means for 2 rabbits) $6 \cdot 2$ and $2 \cdot 3 \mu \mathrm{g} /$ corpus luteum, respectively. 


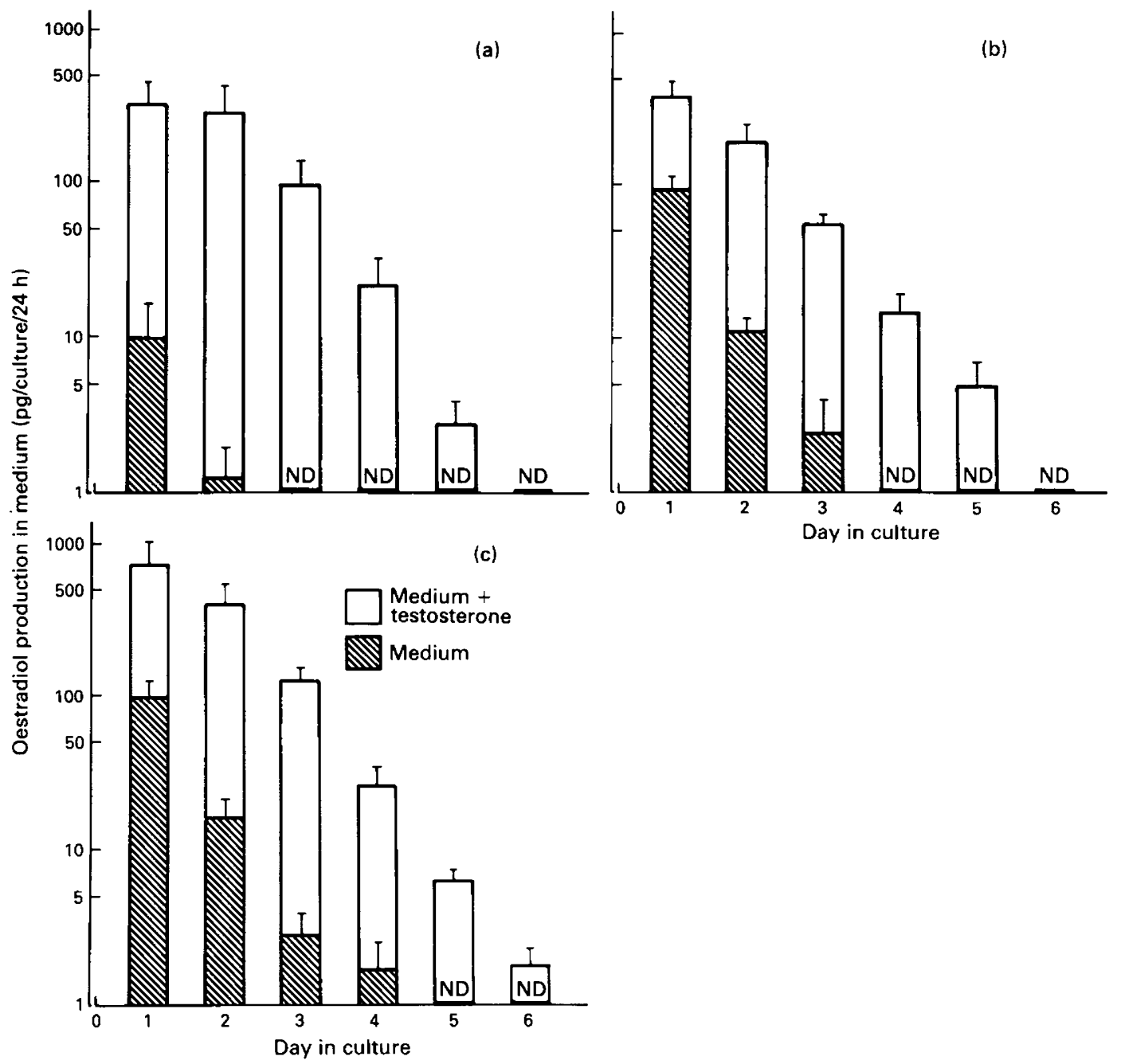

Fig. 8. Daily production of oestradiol in medium. Granulosa lutein cells (a), thecal lutein tissue with attached granulosa lutein cells (b) or whole corpus luteum (c) from Day-1 pseudopregnant rabbits were cultured in the absence or in the presence of testosterone $(10 \mathrm{ng} / \mathrm{ml})$. Oestradiol was measured in same culture medium as that in Fig. 6, but in only 6 animals (testosterone omitted in cultured tissue from one animal). Values are mean \pm s.e.m. for 6 rabbits; $\mathrm{ND}=$ oestradiol not detectable. (c, From Keyes et al., 1984.)

\section{Discussion}

The separation of the thecal compartment from the inner granulosa lutein cells has provided new insights into their respective steroidogenic capacities in the rabbit corpus luteum. The results are in general agreement with those of Mori, Nihnobu, Takeuchi, Onho \& Tojo (1983) who observed higher oestrogen and androgen formation from $\left[{ }^{14} \mathrm{C}\right]$ pregnenolone by the thecal compartment of the human corpus luteum, than by the granulosa lutein cells, although human granulosa lutein cells retain aromatizing activity. The production of oestradiol for several days by the thecal compartment (Fig. 8) indicates that this tissue produced androgen as it does in the Graafian follicle (YoungLai, 1973). By contrast, the granulosa lutein cells produced little, if any, oestradiol in the 


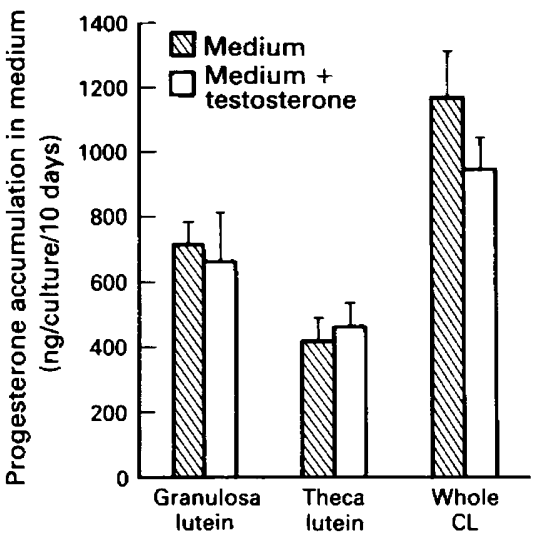

Fig. 9. Effect of testosterone on progesterone production by rabbit luteal tissues. The concentrations of progesterone in medium were measured from the same samples as in Figs 6 and 8 . Values are mean \pm s.e.m. for 6 animals.

Table 1. Tissue content of protein in rabbit luteal tissues in culture

\begin{tabular}{lccc}
\hline & $\begin{array}{c}\text { Granulosa lutein tissue } \\
(\mu \mathrm{g} / \text { culture })\end{array}$ & $\begin{array}{c}\text { Thecal lutein tissue } \\
(\mu \mathrm{g} / \text { culture })\end{array}$ & $\begin{array}{c}\text { Whole corpus } \\
\text { luteum } \\
(\mu \mathrm{g} / \text { culture })\end{array}$ \\
\hline Before culture & $62 \pm 16(4)$ & $83 \pm 5(4)$ & $126 \pm 9(4)$ \\
After 10 days & $34 \pm 4(6)$ & $36 \pm 4(6)$ & $65 \pm 3(8)$ \\
\hline
\end{tabular}

Values are mean \pm s.e.m. for the no. of animals in parentheses.

absence of testosterone added to the medium. Since these cells possessed aromatase activity, it follows that the failure to produce oestradiol is attributable to an inability to synthesize aromatizable androgen. The presence of aromatase activity in granulosa lutein cells provides an explanation for oestradiol synthesis by the thecal compartment, which is heavily contaminated with granulosa lutein cells. An explanation for the progressive loss of oestradiol synthesis by the thecal compartment may be the loss of the capacity for the synthesis of aromatizable androgen, or the absence of gonadotrophic stimulation of thecal tissue. Oestrogen sulphates may be formed as reported by Wise, Ackland, Fleet, Heap \& Walter (1983). The progressive loss of aromatase activity has also been reported in cultures of luteinizing bovine granulosa cells (Henderson \& Moon, 1979) and may be an expression of programmed differentiation initiated by the preovulatory gonadotrophin surge (LH).

From our knowledge of the 4-5-day life span of the corpus luteum in rabbits hypophysectomized the day after ovulation (Keyes et al., 1984; Yuh et al., 1984), we predicted that the corpus luteum would not survive long in culture, possibly less than 5 days. However, this prediction was not borne out by the data: the luteal tissues survived for at least 10 days as indicated by the continued secretion of progesterone and $20 \alpha$-dihydroprogesterone and by the morphology of the luteal cells. This extended steroidogenic activity was not related to the initial inclusion of thecal tissue, since granulosa lutein cells also produced progesterone throughout the experiment. Since we have not cultured pure thecal tissue in the absence of granulosa lutein cells, we cannot state whether the combination of these two types of luteal cells has resulted in an enhancement of progesterone 
synthesis as reported by Lemon \& Mauléon (1982) for the combination of large and small luteal cells of the sow. The gradual decline in steroid production over the last 5-6 days of culture, and the decline in the protein and DNA contents of the explants may be related to the artificial environment of culture or to the lack of appropriate luteotrophic hormones in the medium; oestradiol was not present in the medium after Day 5. We have not investigated the responsiveness of these tissues to hormones, other than to note that addition of testosterone and increased formation of oestradiol did not stimulate the production of progesterone through Day 5 of culture. This observation is not surprising, however, since oestradiol has little effect on luteal growth and progesterone synthesis during the first 4 days after ovulation (Yuh et al., 1984).

The unexpected prolonged survival of luteal tissues forced us to consider the possibility that the luteal tissues were producing oestradiol, which might be acting as an autocrine and luteotrophin. The measurement of oestradiol- $17 \beta$ concentrations in the same medium in which progesterone was measured revealed that oestradiol was produced by the whole corpus luteum and by the thecal compartment for about 3-4 days of culture; after this time, no oestradiol could be detected in the medium. Therefore, an argument could be made that oestradiol had a persistent action, as reported in cultured human breast cancer cells which retain oestradiol for prolonged periods in the absence of protein in the medium (Strobl \& Lippman, 1979). This argument is weakened, however, by the observation that the granulosa lutein cells, which also produced progesterone for 10 days, produced minimal oestradiol for only 1 day of culture. However, we cannot exclude an initial stimulating effect of oestradiol in these cultures, nor can we exclude the possibility that exogenous oestradiol might stimulate progesterone synthesis beyond Day 6 when aromatase activity has been lost.

Another explanation for prolonged survival of luteal tissue in culture is that the programme of differentiation, initiated by the preovulatory gonadotrophin surge $(\mathrm{LH})$, takes longer to be expressed in vitro than in the animal. Thus, the 4-5-day autonomy observed after hypophysectomy may be extended in culture beyond 10 days. One indication of an altered cell activity is the retention of aromatase activity for 5 days in culture (i.e. corresponding to Day 6 after ovulation). Luteal tissue removed on Day 4 of pseudopregnancy had negligible aromatase activity (see 'Results'), indicating a more rapid loss of aromatase activity in vivo. Terranova, Saidapur \& Greenwald (1980) have reported that rabbit corpora lutea removed and incubated $18 \mathrm{~h}$ after hCG injection do not produce oestradiol or androgens although these steroids were measurable in luteal tissue. The absence of oestradiol formation by the rabbit corpus luteum has been reported previously (YoungLai, 1973; Mills \& Savard, 1973; Elbaum \& Keyes, 1976; Suzuki, Mori \& Nishimura, 1977).

We do not know at what point the corpus luteum in organ culture expresses a dependence upon extrinsic hormone, but we know from preliminary work that progesterone synthesis continues beyond Day 10, although in declining quantities. In the rabbit, in which oestradiol is luteotrophic, progesterone secretion is terminated within $24 \mathrm{~h}$ after oestrogen withdrawal on Day 9 (Bill \& Keyes, 1983). Clearly such precipitous events have not occurred in culture, suggesting some autonomy of the tissue in vitro, or a greatly prolonged period of regression. Following this line of reasoning, in culture the corpus luteum might have a degree of autonomy, relying upon de-novo cholesterol synthesis (Kovanen, Goldstein \& Brown, 1978) and any stored cholesterol for steroidogenesis. Its constituent cells, still in contact, would form a mini-corpus luteum with only the adequately nourished cells surviving. A more optimal environment may be provided in culture by the inclusion of serum and lipoproteins. In our experiments, progesterone production was enhanced in the presence of $20 \%$ serum from hypophysectomized rabbits, and dissociated rabbit luteal cells produced increased quantities of progesterone when incubated with lipoprotein (McLean \& Miller, 1983).

This work was supported by grants NIH HD-07127, HD-13645, HD-11311, and NIH Biomedical Research Grant 2-SO7RRO5383-23. 


\section{References}

Bender, E.M., Miller, J.B., Possley, R.M. \& Keyes, P.L. (1978) Steroidogenic effect of $17 \beta$-estradiol in the rabbit: stimulation of progesterone synthesis in prematurely regressing corpora lutea. Endocrinology 103, 1937-1943.

Bill, C.H., II \& Keys, P.L. (1983) 17ß-Estradiol maintains normal function of corpora lutea throughout pseudopregnancy in hypophysectomized rabbits. Biol. Reprod. 28, 608-617.

Burton, K. (1956) A study of the conditions and mechanism of the diphenylamine reaction for the colorimetric estimation of deoxyribonucleic acid. Biochem. J. 62, 315-323.

Deanesly, R., Fee, A.R. \& Parkes, A.S. (1930) Studies on ovulation. II. The effects of hypophysectomy on the formation of the corpus luteum. J. Physiol., Lond. 70, $38-44$.

Elbaum, D.J. \& Keyes, P.L. (1976) Synthesis of 17ßestradiol by isolated ovarian tissues of the pregnant rat: aromatization in the corpus luteum. Endocrinology 99, 573-579.

England, B.G., Niswender, G.D. \& Midgley, A.R., Jr (1974) Radioimmunoassay of estradiol-17 $\beta$ without chromatography. J. clin. Endocr. Metab. 38, 42-50.

Henderson, K.M. \& Moon, Y.S. (1979) Luteinization of bovine granulosa cells and corpus luteum formation associated with loss of androgen-aromatizing ability. J. Reprod. Fert. 56, 89-97.

Keyes, P.L., Yuh, K.-C.M., Bill, C.H., II \& Gadsby, J.E. (1984) New perspectives on the endocrine regulation of the rabbit corpus luteum. In Hormonal Control of the Hypothalamo-Pituitary-Gonadal Axis, pp. 273-288. Eds K. W. McKerns \& Z. Naor. Plenum, New York.

Kovanen, P.T., Goldstein, J.L. \& Brown, M.S. (1978) High levels of 3-hydroxy-3-methylglutaryl coenzyme A reductase activity and cholesterol synthesis in the ovary of the pregnant rabbit. $J$. biol. Chem. 253, 5126-5132.

Lemon, M. \& Mauléon, P. (1982) Interaction between two luteal cell types from the corpus luteum of the sow in progesterone synthesis in vitro. J. Reprod. Fert. 64, 315-323.

Lowry, O.H., Rosebrough, N.J., Farr, A.L. \& Randall, R.J. (1951) Protein measurements with the Folin phenol reagent. J. biol. Chem. 193, 265275.

McLean, M.P. \& Miller, J.B. (1983) Lipoprotein stimulation of progesterone secretion by dissociated rabbit luteal cells in vitro. Biol. Reprod. (Suppl. 1) 28, 76, Abstr.
Mills, T.M. \& Savard, K. (1973) Steroidogenesis in ovarian follicles isolated from rabbits before and after mating. Endocrinology 92, 788-791.

Mori, T., Nihnobu, K., Takeuchi, S., Onho, Y. \& Tojo, S. (1983) Interrelation between luteal cell types in steroidogenesis in vitro of human corpus luteum. $J$. Steroid Biochem. 19, 811-815.

Niswender, G.D. (1973) Influence of the site of conjugation on the specificity of antibodies to progesterone. Steroids 22, 413-424.

Reynolds, E.S. (1963) The use of lead citrate at high $\mathrm{pH}$ as an electron-opaque stain in electron microscopy. $J$. Cell Biol. 17, 208-212.

Rothchild, I. (1981) The regulation of the mammalian corpus luteum. Recent Prog. Horm. Res. 37, 183-298.

Smith, P.E. \& White, W.E. (1931) The effect of hypophysectomy on ovulation and corpus luteum formation in the rabbit. J. Am. Med. Assoc. 97, 1861-1863.

Strobl, J.S. \& Lippman, M.E. (1979) Prolonged retention of estradiol by human breast cancer cells in tissue culture. Cancer Res. 39, 3319-3327.

Suzuki, A., Mori, T. \& Nishimura, T. (1977) Formation of steroid hormones in vitro by developing corpora lutea of the rabbit. $J$. Endocr. 75, 355-361.

Terranova, P.F., Saidapur, S.K. \& Greenwald, G.S. (1980) In vitro steroidogenesis of newly formed corpora lutea and the non-luteal ovary in the rat, rabbit, hamster, and guinea pig. J. Endocr. 84, 101-108.

Vande Wiele, R.L., Boqumil, J., Dyrenfurth, I., Ferin, M., Jewelewicz, R., Warren, M., Rizkallah, T.R. \& Mikhail, G. (1970) Mechanisms regulating the menstrual cycle in women. Recent Prog. Horm. Res. 26, 63-103.

Wise, T., Ackland, N., Fleet, I.R., Heap, R.B. \& Walters, D.E. (1983) Oestrogen metabolism in the endometrium, corpus luteum and ovarian residual tissue of the rabbit. J. Endocr. 96, 201-213.

YoungLai, E.V. (1973) Biotransformation of pregnenolone and progesterone by rabbit ovarian follicles and corpora lutea. Acta endocr., Copenh. 74, $775-782$.

Yuh, K.-C.M. \& Keyes, P.L. (1981) Effects of human chorionic gonadotropin in the rabbit corpus luteum: loss of estrogen receptor and decreased steroidogenic response to estradiol. Endocrinology 108, 1321-1327.

Yuh, K.-C.M., Bill, C.H., II \& Keyes, P.L. (1984) Transient development and function of rabbit corpora lutea after hypophysectomy. Am. J. Physiol. 247, E808-814. 